\title{
Power and Torque Analysis in Electric Vehicle Prototype Design
}

\author{
Denis, Enda Wista Sinuraya, Tejo Sukmadi, Aris Triwiyatno, Bambang Winardi, Karnoto, Yuli \\ Christyono, Wahyudi, Sudjadi, Hermawan, Agung Nugroho, Sidiq Budi Perkasa
}

\author{
Research Scholar \\ Department of Electrical Engineering \\ Diponegoro University \\ Tembalang, Semarang \\ Indonesia
}

\begin{abstract}
Automotive developments led to increased demand for fuel. Vehicle need fossil fuels to move them, while the fossil energy in this world is decreasing over time because fossil energy cannot be renewed. This has triggered the development of the use of electrical energy in the transportation system as a substitute for fossil fuels whose energy source is from renewable energy such as biomass energy (such as methane), hydropower, geothermal power, wind energy, and solar energy. One method that can be done to reduce the use of fossil energy is by utilizing electrical energy as an energy source in cars. In this study, an electric car prototype was designed using a three-phase induction motor with 3 HP power as the main driving force. To find out the power consumption and torque produced, it is necessary to analyze the calculation of power and torque when loaded and without load. In this research, the electric car prototype uses load variants, $40 \mathrm{~kg}, 60 \mathrm{~kg}$, and $100 \mathrm{~kg}$. Where the maximum torque that can be generated by the motor when no load is $9.94 \mathrm{Nm}$ and when it is loaded is a variation of the load of $100 \mathrm{~kg}$ of $11.80 \mathrm{~N} . \mathrm{m}$. Calculation of the maximum power that can be generated by the motor when no load is 1976.94 watts and when loaded is a variation of $100 \mathrm{~kg}$ of 1202.59 watts. The data from the calculation of torque is inversely proportional to power, where the greater the power, the smaller the torque produced.
\end{abstract}

Key Words: Electric Vehicle, Induction Motor, Power, Torque.

\section{INTRODUCTION}

Electric cars are one of the zero-emission vehicles which are an alternative to reduce air pollution and reduce the use of fossil fuels. The government's effort to reduce the increase in air pollution is by issuing Presidential Regulation No. 55 of 2019. "That in order to increase energy efficiency, energy security, and energy conservation in the transportation sector, and the realization of clean energy, clean and environmentally friendly air quality, and Indonesia's commitment to reduce greenhouse gas emissions, it is necessary to accelerate the battery-based electric motor vehicle program (battery electric vehicle) for road transportation [1]. The use of electric cars is considered effective in addition to not causing air pollution and simpler engine construction.

The use of an electric car certainly requires an electric engine, namely an induction motor as a power source for an electric car. An induction motor has advantages over other types of electric motors including strong and simple construction, lower prices, high efficiency under normal circumstances and does not require difficult maintenance [2]. Torque which is an integral part of the motorbike is very important to be optimized, so that the performance of the motor is better. There are three mechanism parameters that are considered when using an induction motor, namely: Speed, rotation, torque generated, and output power. Due to limited measuring instruments, torque measurements cannot be carried out. So that only the calculation of power and torque [3].

The mechanical system is a system related to the chassis, drive and braking. In the use of electric cars, of course, requires a chassis frame that functions as a support for all the loads on the vehicle. The frame is one of the important parts of a car that must have a strong construction to withstand or bear the load of the vehicle. All loads in the vehicle, be it passengers, engine, steering system, and all comfort equipment are all placed on the frame. Therefore, every frame construction must be able to withstand all 
International Journal of Advances in Scientific Research and Engineering (ijasre), Vol 6 (11), November -2020

loads of the vehicle [4]. As for the chassis, it is one part of the vehicle, or in other words, the part that remains when the entire car body is removed [5].

\section{METHODOLOGY}

The flowchart block from the Final Project entitled "Comparative Analysis of Power and Torque in Designing a Prototype of an Electric Vehicle Without Load" can be seen in the following figure:

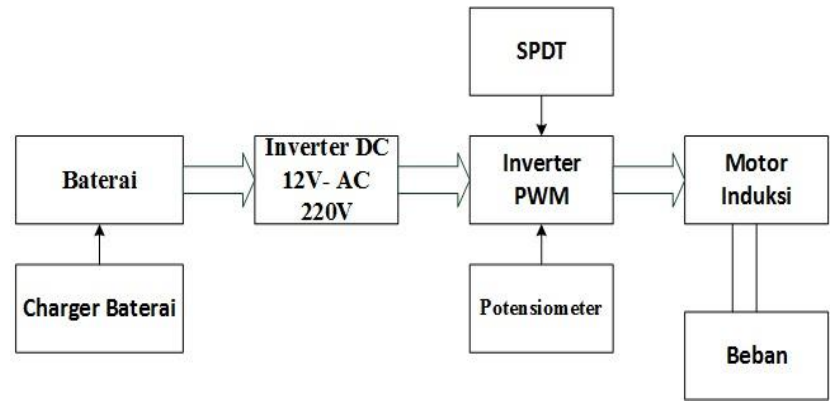

Figure 2.1. Block Diagram

\subsection{Phases Induction Motor}

Induction motors are the most widely used alternating current (ac) motors. the naming comes from the fact that this motor rotor current is not obtained from any particular source. However, it is a current that is induced as a result of the relative difference between the rotation of the rotor and the rotating magnetic field generated by the stator current [6].

Induction motors are very widely used in everyday life both in industry and in households. Induction motors that are commonly used are 3-phase induction motors and 1-phase induction motors. 3-phase induction motors are operated on 3-phase power systems and are widely used in various industrial fields with large capacities. 1-phase induction motors are operated on 1-phase power systems and are widely used especially for household appliances such as fans, refrigerators, water pumps, washing machines and so on because 1-phase induction motors have low output power.

The working principle of a three-phase induction motor is as follows: when the three-phase voltage source is connected to the motor stator coil, then the stator coil (field coil) will arise a synchronous rotating field (ns), the magnitude of which is influenced by the network frequency (f) and the number of pairs pole (P). This stator rotating field will cut the conductor rods in the rotor. As a result, the rotor will have an electromotive force (induced voltage) which is influenced by the frequency of the rotor and the number of rotor conductors [7].

The stator winding connected to a three-phase voltage source will produce a rotating magnetic field at synchronous speed:

$$
N s=\frac{(120 x f)}{p}
$$

$$
\begin{aligned}
& \text { Ns }=\text { Angular Velocity }(\mathrm{rpm}) \\
& \mathrm{f} \quad=\text { Frequency }(\mathrm{Hz}) \\
& \mathrm{P}=\text { Phases }
\end{aligned}
$$

\subsection{Torque}

Torque is a measure of an engine's ability to do work, so torque is energy. The quantity of torque is a derivative quantity that is commonly used to calculate the energy produced from an object rotating on its axis. The formulation of torque is as follows. If an object rotates and has a centrifugal force of $\mathrm{F}$, the object rotates on its axis with a radius of $\mathrm{b}$, then the torque is:

$$
T=F \times b(N . m)
$$

$\mathrm{T}=$ Torque $(\mathrm{N} . \mathrm{m})$

$\mathrm{F}=$ Force $(\mathrm{N})$ 
$\mathrm{b}=$ Radius $(\mathrm{m})$

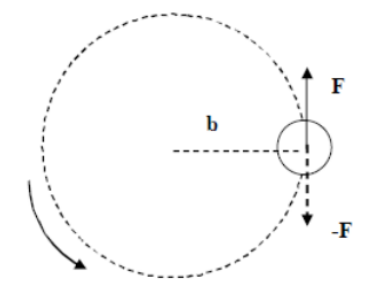

Figure 2.2. Torque

Because of this torque is what causes the object to rotate against its axis, and the object will stop if there is an effort against the torque with the same magnitude in the opposite direction. The torque in an electric motor can be obtained from the quotient between the output power (Watts) and the motor speed (rpm). After obtaining the output power, it can also be obtained the resulting torque results using the formula [8]:

$$
T=\frac{9,55 x P}{n}
$$

$$
\begin{aligned}
& T=\text { Torque }(\mathrm{Nm}) \\
& \mathrm{P}=\text { Electric Power }(\text { Watt }) \\
& \mathrm{n}=\text { Rotational Speed (rpm) } \\
& \text { 9,55=Constant }
\end{aligned}
$$

\subsection{Power}

Electric power is defined as the rate at which energy changes with time in the form of voltage and current. If the voltage is measured in volts, and the current is in amperes, the power is expressed in volts amps. In an electric power system, power is the amount of energy used to do work or business. Electric power is usually expressed in Watts or Horsepower (HP). Horse power is a unit of electrical power where $1 \mathrm{HP}$ is equivalent to 746 Watts [9]. Systematically, the power can be described with the help of Figure 4 below:

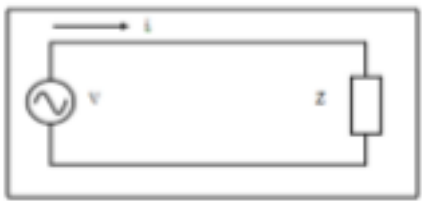

Figure 2.3. Loaded Electrical Circuit

Power is expressed in $\mathrm{P}$, voltage is expressed in $\mathrm{V}$ and current is expressed in $\mathrm{I}$, so the amount of power is expressed in [10]:

$$
P=V x I x \cos \varphi
$$

$$
\begin{aligned}
& \mathrm{P}=\text { Power }(\text { Watt }) \\
& \mathrm{V}=\text { Voltage (Volt) } \\
& \mathrm{I}=\text { Current (Ampere) } \\
& \operatorname{Cos} \varphi=\text { Reactive power }
\end{aligned}
$$

\subsection{Inverter}

Inverter is a power electronic device that functions to convert the alternating voltage to direct voltage and then turn it into alternating voltage again with a changed frequency so that the motor can be controlled according to the desired speed. Inverters are often referred to as Variable Speed Drive (VSD) or Variable Frequency Drive (VFD). The function of the VFD is to control the energy from the main supply to the process through the electric motor shaft, by controlling two quantities, namely torque and speed by using the frequency [11]. 


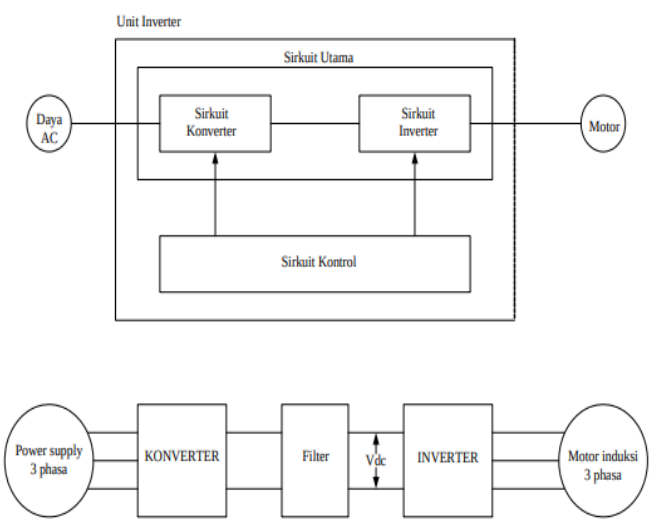

Figure 2.4. Inverter Blok Diagram

\subsection{Inverter TOSVERT VF-S15-2015PM-W}

This type of inverter has the function of converting 1-phase to 3-phase currents with an input of $220 \mathrm{~V}$ to a 3-phase $380 \mathrm{~V}$. This inverter is used to regulate motor speed, by changing the frequency value of an induction motor [12].

Specifications of the inverter type VF-S15-2015PM-W:

1. Dimensions: $10.5 \mathrm{~cm}$ x $13 \mathrm{~cm} 8 \times 13 \mathrm{~cm}$

2. Weight: $1.4 \mathrm{~kg}$

3. Speed control range: $0.1-500 \mathrm{~Hz}$

4. Input: $200 \mathrm{~V}-240 \mathrm{~V}$

5. Capacity: $1500 \mathrm{~V}$

6. Ambient: Rated at $40^{\circ} \mathrm{C}$

7. Output: 3 phase

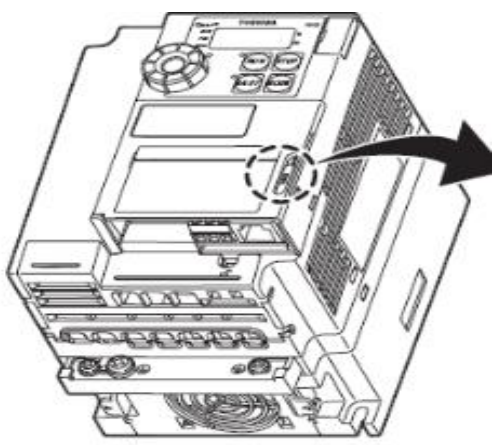

Figure 2.5. Inverter TOSVERT VF-S15-2015PM-W

\subsection{Accumulator}

Battery is a cell or secondary element and is a source of direct electric current that can convert chemical energy into electrical energy. Batteries include electrochemical elements that can affect reagents, so they are called secondary elements. The positive pole of the battery uses an oxide plate and the negative pole uses a lead plate, while the electrolyte solution is a solution of sulfuric acid [13].

When the battery is used, a chemical reaction occurs which results in deposition at the anode (reduction) and cathode (oxidation). As a result, in a certain time between anode and cathode there is no potential difference, meaning that the battery is empty.

In order for the battery to be used again, it must be charged by flowing an electric current in the opposite direction to the electric current issued by the battery. When the battery is charged an electric charge will collect. The collection of the amount of electric charge is expressed in ampere hours, which is called battery power. In reality, using a battery cannot remove all of the energy stored in the battery. Therefore, the battery has yield or efficiency [14]. 
International Journal of Advances in Scientific Research and Engineering (ijasre), Vol 6 (11), November -2020

\section{RESULT AND DISCUSSION}

\subsection{Voltage Source Testing}

The input voltage source of the electric car drive system is a three-phase AC voltage source. Before becoming a three-phase voltage source, the DC voltage from the battery is connected to a power inverter which converts the DC voltage into single-phase AC voltage. Table 1 shows the measurement results of the single-phase AC voltage that enter the VFD inverter system.

Table 3.1. Single-phase AC voltage source testing

\begin{tabular}{|c|c|}
\hline Voltage & Current \\
\hline $230 \mathrm{~V}$ & $0,93 \mathrm{~A}$ \\
\hline
\end{tabular}

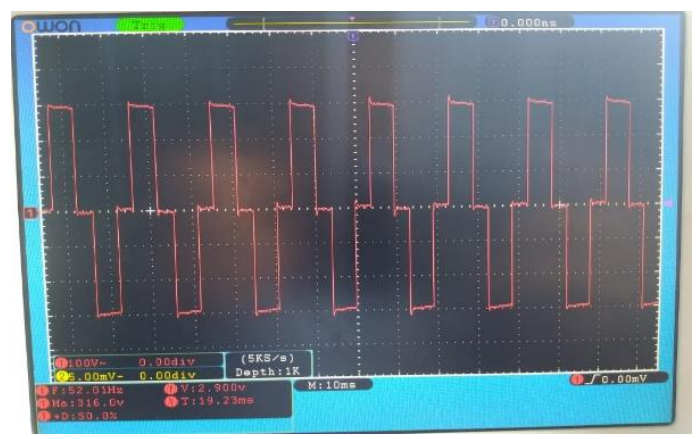

Figure 3.1. Single Phase DC to AC Inverter Output Wave

The voltage imbalance value can be calculated to estimate the unbalance value of the three-phase voltage source that can be tolerated or not. The voltage unbalance value can be calculated based on the following equation:

$$
=\frac{\text { Maximum Deviation }}{\text { average }}
$$

Table 3.2. Calculation of line to line voltage deviation

\begin{tabular}{|c|c|c|}
\hline Parameter & Value & average deviation \\
\hline Voltage $\mathrm{R}-\mathrm{S}$ & $386,25 \mathrm{~V}$ & $1,45 \mathrm{~V}$ \\
\hline Voltage $\mathrm{S}-\mathrm{T}$ & $384,7 \mathrm{~V}$ & $0,1 \mathrm{~V}$ \\
\hline Voltage $\mathrm{T}-\mathrm{R}$ & $383,5 \mathrm{~V}$ & $1,3 \mathrm{~V}$ \\
\hline Maximum value & $386,25 \mathrm{~V}$ & $1,45 \mathrm{~V}$ \\
\hline Average & $384,8 \mathrm{~V}$ & $0,95 \mathrm{~V}$ \\
\hline
\end{tabular}

From the calculation data in table 2, it can be seen that the three-phase voltage average value is $384.8 \mathrm{~V}$ and the maximum deviation value of the three-phase voltage is $1.45 \mathrm{~V}$. Based on equation (4), the three-phase line to line voltage imbalance is 0.0037 or $0.39 \%$.

Based on the NEMA MG-1-1998 standard regarding electric machines, the three-phase voltage used by the electric engine voltage source is only allowed to have an imbalance of $1 \%$. This shows that the three-phase line to line voltage and the measured line to neutral voltage can be used for the voltage source for three-phase induction motors.

\subsection{No-Load Power and Torque Calculations}

\subsubsection{No-Load Power Calculation}

Table 3.3. Measurement results of the Induction Motor Input Voltage and Current

\begin{tabular}{|c|c|c|c|}
\hline Frequency $(\mathbf{H z})$ & Voltage & Current & Cos phi \\
\hline 5 & 108,08 & 5,75 & 0,914 \\
\hline 10 & 131,63 & 5,5 & 0,93 \\
\hline 15 & 167,9 & 5.49 & 0,927 \\
\hline 20 & 204,71 & 5,39 & 0,95 \\
\hline
\end{tabular}


International Journal of Advances in Scientific Research and Engineering (ijasre), Vol 6 (11), November -2020

\begin{tabular}{|c|c|c|c|}
\hline 25 & 233,39 & 5,43 & 0,957 \\
\hline 30 & 265,14 & 5,44 & 0,952 \\
\hline 35 & 297,9 & 5,31 & 0,941 \\
\hline 40 & 327,36 & 5,32 & 0,961 \\
\hline 45 & 360,08 & 5,28 & 0,97 \\
\hline 50 & 389,7 & 5,34 & 0,95 \\
\hline
\end{tabular}

By knowing the voltage, current and cos phi data on the electric motor when it is not loaded. Then the motor output power can be calculated based on equation (4).

Table 3.4. Induction Motor Output Power

\begin{tabular}{|c|c|}
\hline Frequency (Hz) & Power (Watt) \\
\hline 5 & 568,01 \\
\hline 10 & 673,28 \\
\hline 15 & 854,48 \\
\hline 20 & 1048,21 \\
\hline 25 & 1212,81 \\
\hline 30 & 1373,12 \\
\hline 35 & 1488,51 \\
\hline 40 & 1673,63 \\
\hline 45 & 1844,18 \\
\hline 50 & 1976,94 \\
\hline
\end{tabular}

In table 4 it can be seen that, in the second test when the frequency is $10 \mathrm{~Hz}$, the induction motor output power is 673.28 watts. At a frequency of $30 \mathrm{~Hz}$, the induction motor output power is 1373.12 watts. At a frequency of $50 \mathrm{~Hz}$, the induction motor output power is 1976.94 watts. This shows the increase in the value of the frequency imposed on the motor in proportion to the increase in the value of the power required. From the data in table 4, a graph can be made in Figure 8.

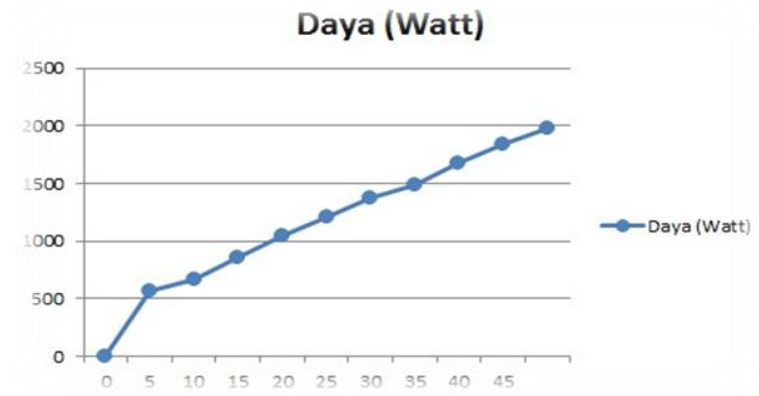

Figure 3,2. Graph of Motor Power Calculation Without Load

\subsubsection{No-Load Torque Calculation}

Table 3.5. Power And Speed Testing

\begin{tabular}{|c|c|c|}
\hline Frequency (Hz) & Power (Watt) & Rotational Speed (rpm) \\
\hline 5 & 568,01 & 300 \\
\hline 10 & 673,28 & 600 \\
\hline 15 & 854,48 & 900 \\
\hline 20 & 1048,21 & 1200 \\
\hline 25 & 1212,81 & 1500 \\
\hline 30 & 1373,12 & 1800 \\
\hline 35 & 1488,51 & 2100 \\
\hline 40 & 1673,63 & 2400 \\
\hline 45 & 1844,18 & 2700 \\
\hline 50 & 1976,94 & 3000 \\
\hline
\end{tabular}


International Journal of Advances in Scientific Research and Engineering (ijasre), Vol 6 (11), November -2020

The results of the power and speed test are shown in table 5, so it can be calculated using equation (3). To get the results of calculations on other data, use the same equation. Then the calculation of motor torque can be done. In Table 6 is the data from the calculation of the torque of the induction motor without load.

Table 3.6. Hasil Perhitungan Torsi Motor Induksi Tanpa Beban

\begin{tabular}{|c|c|c|c|}
\hline Frequency (Hz) & Power (Watt) & Rotational Speed (rpm) & Torque (N.m) \\
\hline 5 & 312,08 & 300 & 9,93 \\
\hline 10 & 369,93 & 600 & 5,88 \\
\hline 15 & 468,89 & 900 & 4,97 \\
\hline 20 & 575,33 & 1200 & 4,57 \\
\hline 25 & 664,96 & 1500 & 4,23 \\
\hline 30 & 754,15 & 1800 & 4,00 \\
\hline 35 & 817,57 & 2100 & 3,71 \\
\hline 40 & 918,46 & 2400 & 3,65 \\
\hline 45 & 1011,42 & 2700 & 3,57 \\
\hline 50 & 1083,72 & 3000 & 3,44 \\
\hline
\end{tabular}

In table 6 it can be seen that, in the second test when the frequency is $10 \mathrm{~Hz}$, the calculation torque is $5.88 \mathrm{~N} . \mathrm{m}$. At a frequency of $30 \mathrm{~Hz}$, the calculation torque is $4.00 \mathrm{~N} . \mathrm{m}$. At a frequency of $50 \mathrm{~Hz}$, the calculation torque is 3.44 N.m. This shows that the increase in the frequency value imposed on the motor is inversely proportional to the calculated torque value. From the data in Table 6, a graph can be made in Figure 9.

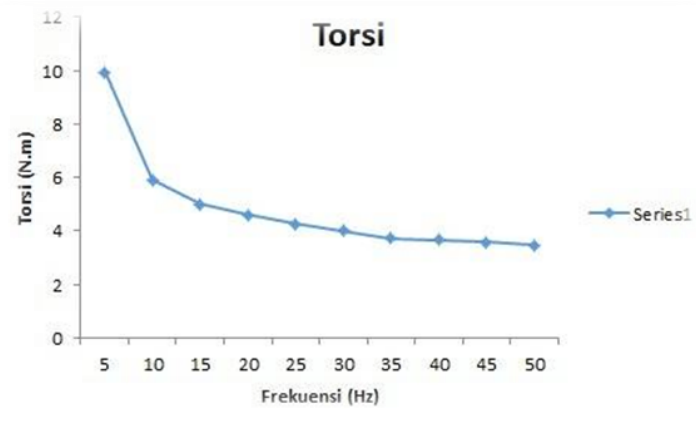

Figure 3.3. No-Load Torque Calculation Graph

\subsubsection{Perbandingan Daya dan Torsi Tanpa Beban}

Table 3.7. Comparison of Power and Torque Without Load

\begin{tabular}{|c|c|}
\hline Power $\mathbf{( W a t t )}$ & Torque $(\mathbf{N m})$ \\
\hline 568,01 & 9,93 \\
\hline 673,28 & 5,88 \\
\hline 854,48 & 4,97 \\
\hline 1048,21 & 4,57 \\
\hline 1212,81 & 4,23 \\
\hline 1373,12 & 4,00 \\
\hline 1488,51 & 3,71 \\
\hline 1673,63 & 3,65 \\
\hline 1844,18 & 3,57 \\
\hline 1976,94 & 3,44 \\
\hline
\end{tabular}

From table 7 it can be seen that, at an induction motor power of 673.28 watts, the calculated torque is 9.93 N.m. At a motor power of 1373.12 watts, the torque is calculated at $4.00 \mathrm{~N} . \mathrm{m}$. At a motor power of 1976.94 watts, the torque is calculated as 3.44 N.m. So it can be concluded that the ratio of power and torque is inversely proportional. This is in accordance with the theory, where the greater the motor speed, the resulting torque will decrease. From the data in Table 7, a graph can be made in Figure 10. 
International Journal of Advances in Scientific Research and Engineering (ijasre), Vol 6 (11), November -2020

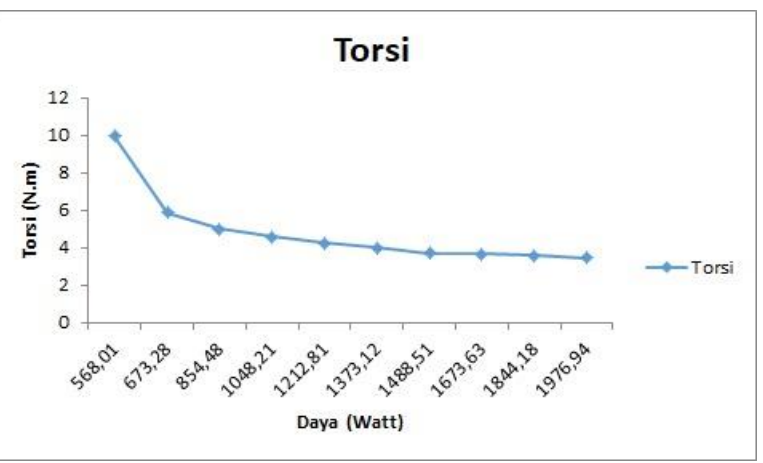

Figure 3.4. Comparison of Power and Torque Without Load

\subsection{Loaded Power and Torque Calculation}

\subsubsection{Calculation of Load Variation Power}

Table 3.8. The results of measuring the Voltage and Input Current of an Induction Motor with a Load Variation of $40 \mathrm{Kg}$

\begin{tabular}{|c|c|c|c|}
\hline Frequency (Hz) & Voltage (V) & Current (A) & $\operatorname{Cos} \boldsymbol{\varphi}$ \\
\hline 5 & 110,08 & 5,81 & 0,913 \\
\hline 10 & 136,80 & 5,52 & 0,911 \\
\hline 15 & 160,94 & 5,56 & 0,935 \\
\hline 20 & 206,08 & 5,45 & 0,921 \\
\hline
\end{tabular}

Table 3.9. The results of measuring the Voltage and Input Current of an Induction Motor with a Load Variation of $60 \mathrm{Kg}$

\begin{tabular}{|c|c|c|c|}
\hline Frequency (Hz) & Voltage (V) & Current (A) & $\operatorname{Cos} \boldsymbol{\varphi}$ \\
\hline 5 & 112,8 & 6 & 0,941 \\
\hline 10 & 140,6 & 5,8 & 0,961 \\
\hline 15 & 179,8 & 5,69 & 0,971 \\
\hline 20 & 210,23 & 5,58 & 0,941 \\
\hline
\end{tabular}

Tabel 3.10. The results of measuring the Voltage and Input Current of an Induction Motor with a Load Variation of $100 \mathrm{Kg}$

\begin{tabular}{|c|c|c|c|}
\hline Frequency (Hz) & Voltage (V) & Current (A) & $\operatorname{Cos} \boldsymbol{\varphi}$ \\
\hline 5 & 114,4 & 6,2 & 0,951 \\
\hline 10 & 142,3 & 5,9 & 0,971 \\
\hline 15 & 181,7 & 5,8 & 0,972 \\
\hline 20 & 216,2 & 5,9 & 0,942 \\
\hline
\end{tabular}

By knowing the power data and rotational speed. Then the motor torque can be calculated based on equation (4).

Table 3.11. Calculation of Induction Motor Power with Load Variations of $40 \mathrm{~kg}, 60 \mathrm{~kg}$, and $100 \mathrm{~kg}$

\begin{tabular}{|c|c|c|c|}
\hline \multirow{2}{*}{ Frequency (Hz) } & \multicolumn{3}{|c|}{ Power (watt) } \\
\cline { 2 - 4 } & $\mathbf{4 0 k g}$ & $\mathbf{6 0 k g}$ & $\mathbf{1 0 0 k g}$ \\
\hline 5 & 583,92 & 636,86 & 674,52 \\
\hline 10 & 687,92 & 783,67 & 815,22 \\
\hline 15 & 836,66 & 993,39 & $1024 ., 35$ \\
\hline 20 & 1034,40 & 1147,39 & 1201,59 \\
\hline
\end{tabular}

In table 11 it can be seen that, in the second test when the frequency is $10 \mathrm{~Hz}$, the output power of the induction motor with a load variation of $40 \mathrm{~kg}$ is 687.92 watts, $60 \mathrm{~kg}$ load variation is 783.67 watts, $100 \mathrm{~kg}$ load variations are 815.22 watts. in the third test when the frequency is $15 \mathrm{~Hz}$, the output power of the induction motor with a load variation of $40 \mathrm{~kg}$ is 836.66 watts, a variation of a load of $60 \mathrm{~kg}$ is 993.39 watts, a variation of a load of $100 \mathrm{~kg}$ is 1024.35 watts. This shows that the more free the load is applied, the greater the power required. The increase in the value of the frequency applied to the motor is proportional to the increase in the value of the power required. From the data in table 11, a graph can be made in Figure 11. 


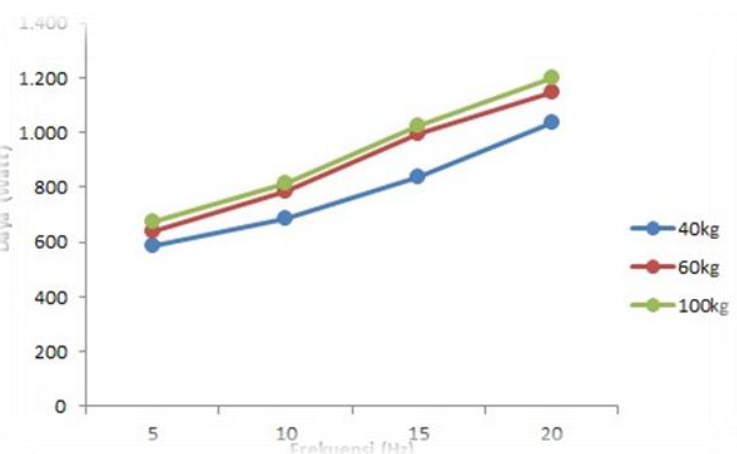

Figure 3.5. Graph of Calculation of Motor Power with Variation of Load

\subsubsection{Calculation of Load Variation Torque}

Table 3.12. Test Results Data Power and Load Speed $40 \mathrm{Kg}$

\begin{tabular}{|c|c|c|}
\hline Frequency (Hz) & Power (watt) & Rotational Speed (rpm) \\
\hline 5 & 321,156 & 300 \\
\hline 10 & 378,356 & 600 \\
\hline 15 & 460,163 & 900 \\
\hline 20 & 568,92 & 1200 \\
\hline
\end{tabular}

Table 3.13. Test Results Data Power and Load Speed $60 \mathrm{Kg}$

\begin{tabular}{|c|c|c|}
\hline Frequency (Hz) & Power (watt) & Rotational Speed (rpm) \\
\hline 5 & 350,273 & 300 \\
\hline 10 & 431,0185 & 600 \\
\hline 15 & 546,3645 & 900 \\
\hline 20 & 631,0645 & 1200 \\
\hline
\end{tabular}

Tabel 3.14. Test Results Data Power and Load Speed $100 \mathrm{Kg}$

\begin{tabular}{|c|c|c|}
\hline Frequency (Hz) & Power (watt) & Rotational Speed (rpm) \\
\hline 5 & 370,986 & 184,69 \\
\hline 10 & 448,371 & 459,78 \\
\hline 15 & 563,3925 & 643,85 \\
\hline 20 & 660,8745 & 798,35 \\
\hline
\end{tabular}

The results of the power and speed test are shown in table 5, so it can be calculated using equation (4). To get the results of calculations on other data, use the same equation. Then the calculation of motor torque can be done. In table 15 . is the data from the calculation of the torque of an induction motor without load.

Table 3.15. Calculation Results of Torque Induction Motor with Variation of Load

\begin{tabular}{|c|c|c|c|}
\hline \multirow{2}{*}{ Frequency } & \multicolumn{3}{|c|}{ Torque (Nm) } \\
\cline { 2 - 4 } & $\mathbf{4 0} \mathbf{~ k g}$ & $\mathbf{6 0} \mathbf{~ k g}$ & $\mathbf{1 0 0} \mathbf{~ k g}$ \\
\hline 5 & 10,22 & 11,15 & 11,80 \\
\hline 10 & 6,02 & 6,86 & 7,13 \\
\hline 15 & 4,88 & 5,79 & 5,97 \\
\hline 20 & 4,52 & 5,02 & 5,25 \\
\hline
\end{tabular}

In table 15 it can be seen that, in the second test when the frequency is $5 \mathrm{~Hz}$, the torque of the induction motor with a load variation of $40 \mathrm{~kg}$ is $10.22 \mathrm{n} . \mathrm{m}$, the variation in the load of $60 \mathrm{~kg}$ is $11.15 \mathrm{n} . \mathrm{m}$, the variation in the load is $100 \mathrm{~kg}$ of $11.809 \mathrm{~nm}$ In the third test when the frequency is $15 \mathrm{~Hz}$, the calculated torque of the induction motor with a load variation of $40 \mathrm{~kg}$ is $4.88 \mathrm{n} . \mathrm{m}$, $60 \mathrm{~kg}$ load variation is 5.79 n.m, $100 \mathrm{~kg}$ load variation is 5.97 n.m. This shows that the difference in the load imposed results in the resulting torque different. The heavier the load, the lower the rotational speed of the motor. This will result in the resulting 
International Journal of Advances in Scientific Research and Engineering (ijasre), Vol 6 (11), November -2020

torque even greater. From the data in table 15, a graph can be made in Figure 12.

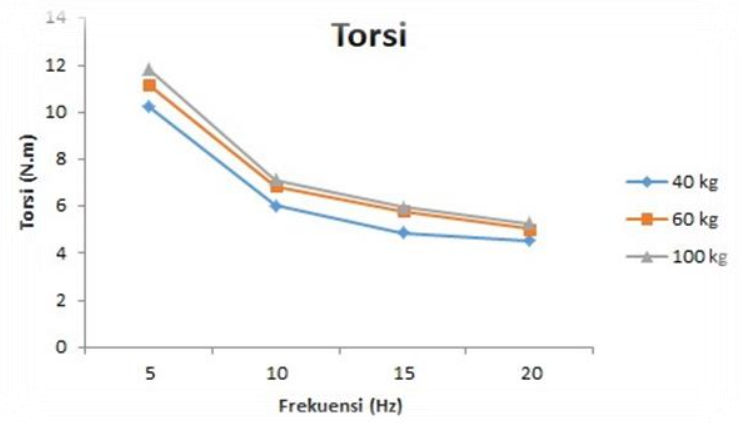

Figure 3.6. Graph of Motor Torque Calculation with Variation in Load

\subsection{Performance Testing}

Performance testing is carried out to determine the speed of the electric car being made, as well as to determine the performance of the rear wheel drive. In testing this performance using the acceleration method. Where the car is driven at a distance of $100 \mathrm{~m}$ and $200 \mathrm{~m}$ by calculating the travel time on the track. The test was carried out on the road along the front of the Faculty of Economics and Business, Diponegoro University (direction of the Faculty of Medicine).

\subsubsection{Electric Vehicle Prototype Specifications}

Table 3.16. Electric Vehicle Prototype Specifications

\begin{tabular}{|l|l|}
\hline Electric Vehicle Prototype Specifications \\
\hline Engine & 3 Phases Induction Motor \\
\hline Type & $3 \mathrm{HP}$ \\
\hline Power & $15 \mathrm{~kg}$ \\
\hline Weight & $2840 \mathrm{rpm}$ \\
\hline Speed & \\
\hline Dimension & $155 \mathrm{~m}$ \\
\hline Length & $95 \mathrm{~m}$ \\
\hline Width & $80 \mathrm{~cm}$ \\
\hline Height & $+-60 \mathrm{~kg}$ \\
\hline Kerb weight & \\
\hline Chassis & Besi Hallow \\
\hline Type & Artco 3.25/3.00 - 8 (13 X 3) \\
\hline Tyres & Disc \\
\hline Brakes & \\
\hline Electricity & $12 \mathrm{v} / 65$ AH Battery \\
\hline Voltage Source & $\begin{array}{l}12 \text { dc to 220 vac Inverter 3000 } \\
\text { watt }\end{array}$ \\
\hline AC Voltage & Variable Frequency Drive (VFD) \\
\hline Speed Control & Variable Frequency Drive (VFD) \\
\hline Controller & \\
\hline
\end{tabular}

\subsubsection{Electric vehicle Mileage}

Table 3.17. Testing Results Distance $100 \mathrm{~m}$

\begin{tabular}{|c|c|c|}
\hline No & Distance $(\mathbf{m})$ & Times $(\mathbf{s})$ \\
\hline 1 & 100 & 16,28 \\
\hline 2 & 100 & 17,84 \\
\hline 3 & 100 & 16,51 \\
\hline
\end{tabular}

From these data, the average travel time can be obtained at a distance of $100 \mathrm{~m}$ with the following calculations:

Average Travel Time $=\frac{(16,28+17,84+16,51)}{3}=16,87 \mathrm{~S}$ 
International Journal of Advances in Scientific Research and Engineering (ijasre), Vol 6 (11), November -2020

Table 3.18. Induction Motor Torque Calculation Results Without Load

\begin{tabular}{|c|c|c|}
\hline No & Distance $(\mathrm{m})$ & Times $(\mathrm{s})$ \\
\hline 1 & 100 & 28,43 \\
\hline 2 & 100 & 26,74 \\
\hline 3 & 100 & 26,45 \\
\hline
\end{tabular}

From this data, it is obtained the average travel time at a distance of $100 \mathrm{~m}$ with the following calculations:

$$
\text { average time }=\frac{(28,43+26,74+26,45)}{3}=27,20 \mathrm{~S}
$$

The electric car made is a prototype so that the most efficient drive system used is the chain and gear mechanism. The working process of the power transfer system can be concluded as successful if it has passed a speed test on a straight line along $100 \mathrm{~m}$ and $200 \mathrm{~m}$, which has been proven by the results of the average travel time.

\section{CONCLUSION}

The data from the calculation of torque is inversely proportional to power, where the greater the power, the smaller the torque produced. This is in accordance with the theory, because when the power increases, the motor rotational speed also increases. The data from the power test results are directly proportional to the frequency, where the greater the frequency used, the greater the motor

power. Induction motors have a weakness in torque, this is because the gear box is not installed to increase the torque of the induction motor.

\section{REFERENCES}

[1] Peraturan Presiden Republik Indonesia No. 55 Tahun 2019.

[2] Rizal, Angga Ghazali, "Metode Perhitungan Efisiensi Motor Induksi Yang Sedang Beroperasi”, Universitas Indonesia, Depok, 2011.

[3] Tom, Denton “Automobile Electrical and Electronic Systems", Bath press, London.

[4] Sadikin, Ali, "Perancangan Rangka Chasis Mobil Listrik Untuk 4 Penumpang Menggunakan Software 3D Siemens NX8" Laporan Tugas Akhir, Teknik Mesin, Universitas negeri semarang, Semarang, 2013.

[5] Fauzi, Ficky, “Analisis Perancangan Penggerak Belakang Gokart 150 cc DOHC” Laporan Tugas Akhir, Teknik Mesin, Universitas Muhammadiyah Yogyakarta, Yogyakarta, 2016.

[6] Zuhal, Dasar Teknik Tenaga Listrik Dan Elektronika Daya, Gramedia Pustaka Utama, Jakarta, 1998.

[7] Henri Wijaksana, Ayub Subandi, “ Rancang Bangun Sistem Kelistrikan dan Sistem Manajemen Baterai Pada Kendaraan Listrik" Makalah Tugas Akhir, Bandung, 2015.

[8] Chapman, Stephen J, "Electric Machinery Fundamentals",Third Edit ion Mc Graw Hill Companies, New York, 1999.

[9] Shintawaty,Lethifa "Peranan Daya Reaktif Pada Sistem Kelistrikan" Jurnal Desiminasi Teknologi , Volume 1, No 2, Juli 2013.

[10] Buyung, Surianto, “Analisa Perbandingan Daya dan Torsi Pada Alat Pemotorng Rumput Elektrik (APRE)”, Jurnal Voering Vol. 3 No.1 Juli 2018

[11] Evalin N, Abdul A, Zulfikar, "Pengaturan Kecepatan Putaran Motor Induksi 3 Fasa Menggunakan Programable Logic Controller” Journal of Electrical Technology, Vol. 3, No. 2, Sumatera Utara, Juni 2018.

[12] Tosvert VF-S15 Instruction Manual, Web version, Toshiba Corporation, Tokyo, Jepang.

[13] Iman Setiono, “Akumulator, Pemakaian dan Perawatannya”, Jurnal Metana vol. 11, No. 1, 31-36, Juli 2015.

[14] Putra, Hermawan Permana, "Studi Karakteristik Pelepasan Muatan Baterai Lead Acid Terhadap Variasi Beban RLC, Skripsi, Universitas Indonesia, Depok, 2010. 